\title{
Pengaruh Etanolamina Terhadap Pembentukan Fasa, Ukuran Partikel, dan Luas Permukaan Spesifik Nanotitania Menggunakan Metode Sol Gel
}

\author{
Renita Maharani Fauzi ${ }^{(1 \mathrm{a})^{*}}$, Posman Manurung ${ }^{(\mathrm{b})}$, Dita Rahmayanti ${ }^{(\mathrm{c}),}$ \\ Yanti Yulianti ${ }^{(\mathrm{d})}$
}

\author{
Program Studi Magister Fisika, Universitas Lampung, Bandar Lampung, Indonesia, 35141 \\ Email: ${ }^{(a)}$ renitarenita4@gmail.com, ${ }^{(b)}$ reip65@yahoo.com., ${ }^{(c)}$ dita.rahmayanti21@gmail.com \\ (d)yanti.yulianti@fmipa.unila.ac.id
}

Diterima (15 Desember 2020), Direvisi (23 Juli 2021)

\begin{abstract}
Nanotitania has been prepared by sol gel method using ethanolamine as surfactant. This research was conducted to determine the effect of ethanolamine on the phase formation, particle size and surface area of $\mathrm{TiO}_{2}$. In this study Ti-butoxide was used as a precursor and ethanol as a solvent, and then $\mathrm{HCl}$. The amount of ethanolamine was varied to $0 ; 0.5 ; 1 ; 1.5$; and $2 \mathrm{ml}$. The samples were calcined at a temperature of $500^{\circ} \mathrm{C}$ for 4 hours. $\mathrm{TiO}_{2}$ was characterized using X-Ray Diffraction (XRD), Transmission Electron Microscopy (TEM), and Surface Area Analyzer (SAA) with BET method. The results of XRD characterization showed that in samples $A-0.0$ and $A-0.5$ an anatase phase was formed, whereas in the sample A-1,0 and A1,5 an anatase, brookite, and rutile phases were formed with a weight percentage of $58 \pm 2 \% \mathrm{wt} ; 27 \pm 2 \%$ $w t$, and $15 \pm 0,4 \% w t$. Meanwhile, for sample A-1,5 it is $70 \pm 2 \% w t, 25 \pm 2 \% w t$, and $5 \pm 0,3 \% w t$. Sample $A-2.0$ only produced anatase and brookite phases with weight percentages of $79 \pm 2 \% \mathrm{wt}$ and $21 \pm 2 \% \mathrm{wt}$. The results of TEM characterization using ImageJ software show that the $\mathrm{TiO}_{2}$ particle size in sample A-1,0 was $16 \pm 1,0 \mathrm{~nm}$. The results of the analysis surface area of sample A-1, produced the largest specific surface area, that is $172 \mathrm{~m}^{2} / \mathrm{g}$, the smallest specific surface area was produced in sample A-2,0 that is $72,07 \mathrm{~m}^{2} / g$.
\end{abstract}

Keywords: anatase, brookite. ethanolamine, nanotitania, rutile,

\begin{abstract}
Abstrak. Nanotitania telah dipreparasi dengan metode sol gel menggunakan etanolamina sebagai surfaktan. Penelitian ini dilakukan untuk mengetahui pengaruh etanolamina terhadap pembentukan fasa, ukuran partikel, dan luas permukaan $\mathrm{TiO}_{2}$. Dalam penelitian ini Ti-butoksida dipakai sebagai prekusor dan etanol sebagai pelarut, kemudian $\mathrm{HCl}$. Jumlah etanolamina yang divariasikan adalah $0 ; 0.5 ; 1 ; 1.5 ;$ dan $2 \mathrm{ml}$. Sampel di kalsinasi pada suhu $500^{\circ} \mathrm{C}$ selama 4 jam. $\mathrm{TiO}_{2}$ dikarakterisasi menggunakan $X$-Ray Diffraction (XRD), Transmission Electron Microscopy (TEM), dan Surface Area Analyzer (SAA) dengan metode BET. Hasil karakterisasi XRD menunjukkan bahwa pada sampel A-0,0 dan A-0,5 terbentuk fasa anatase, sedangkan pada sampel A-1,0 dan A-1,5 terbentuk fasa anatase, brukit, dan rutil dengan presentase berat masing-masing $58 \pm 2 \% \mathrm{wt} ; 27 \pm 2 \% \mathrm{wt}$, dan $15 \pm 0,4 \% \mathrm{wt}$. Sedangkan untuk sampel A-1,5 sebesar $70 \pm 2$ $\% \mathrm{wt} ; 25 \pm 2 \% \mathrm{wt}$, dan $5 \pm 0,3 \% \mathrm{wt}$. Sampel A-2,0 hanya menghasilkan fasa anatase dan brukit saja dengan presentase berat masing-masing $79 \pm 2 \% \mathrm{wt}$ dan $21 \pm 2 \% \mathrm{wt}$. Hasil karakterisasi TEM dengan menggunakan perangkat lunak ImageJ menunjukkan bahwa ukuran partikel $\mathrm{TiO}_{2}$ pada sampel A-1,0 adalah $16 \pm 1,0 \mathrm{~nm}$. Hasil analisis luas permukaan spesifik sampel A-1,0 menghasilkan luas permukaan spesifik terbesar yaitu $172 \mathrm{~m}^{2} / \mathrm{g}$, luas permukaan spesifik terkecil dihasilkan pada sampel A-2,0 yaitu $72,07 \mathrm{~m} / \mathrm{g}$.
\end{abstract}

Kata kunci: anatase, brukit, etanolamina, nanotitania, rutil 


\section{PENDAHULUAN}

Akhir-akhir ini, nanoteknologi menjadi salah satu teknologi yang berkembang pesat dan berkontribusi besar pada perkembangan sains material [1]. Jenis nanoteknologi yang sedang dikembangkan adalah nanomaterial. Nanomaterial memiliki sifat elektrik yang besar, luas permukaan yang luas, sifat mekanik, optik dan kemagnetan yang lebih tinggi dibandingkan pada saat berbentuk limpahan (bulk) [2].

Bahan nanomaterial yang sedang dikembangkan dan diaplikasikan adalah titanium dioksida $\left(\mathrm{TiO}_{2}\right)$ atau titania sebagai material alternatif dalam berbagai aspek, terutama berkaitan dengan ukuran partikelnya. Semakin kecil partikelnya, maka semakin luas permukaan yang aktif untuk bereaksi sehingga semakin beragam potensi penerapannya [3]. $\quad \mathrm{TiO}_{2}$ banyak dimanfaatkan antara lain untuk dijadikan sensor, salah satunya sensor gas [4], dan $\mathrm{TiO}_{2}$ paling banyak dimanfaatkan sebagai fotokatalis [5][6].

Secara struktur $\mathrm{TiO}_{2}$ memiliki tiga bentuk polimorf yaitu anatase, rutil, dan brukit. Anatase dan rutil memiliki struktur kristal tetragonal, sedangkan brukit memiliki struktur kristal orthorombik. Fasa anatase dan brukit merupakan fasa metastabil yang mudah berubah menjadi fasa rutil ketika dipanaskan [7].

Ada dua metode sintesis $\mathrm{TiO}_{2}$ yaitu metode fisik dan metode kimia. Kedua metode tersebut memiliki kekurangan dan kelebihan masing-masing. Metode fisika menghasilkan material dalam jumlah besar, tetapi ukurannya tidak memadai untuk nanometer. Sedangkan metode kimia dapat dibuat sampai ukuran nanometer [8]. Sampai saat ini, struktur nano $\mathrm{TiO}_{2}$ telah diperoleh dengan metode yang berbeda seperti hidrotermal, solvotermal, metode oksidasi langsung, deposisi uap kimia, elektrodeposisi dan sol gel [9]-[12] .

Diantara semua metode, teknik sol gel sangat berguna untuk preparasi material amorf dan kristal. Ini menawarkan keuntungan seperti kemungkinan mendapatkan bahan hibrida homogen pada suhu rendah. Dengan metode sol-gel, $\mathrm{TiO}_{2}$ berstruktur nano telah banyak disintesis dari hidrolisis prekursor titanium. Keuntungan dari proses sol-gel adalah tidak mahal, serta metode pemrosesan yang mudah untuk pembuatan bubuk titania [13].

Pada penelitian sintesis nanotitania dengan menggunkan metode sol gel, beberapa diantaranya ada yang menambahkan variasi surafktan untuk melihat bagaimana pengaruh surfaktan terhadap sifat nanotitania tersebut. Hasilnya, pada beberapa penelitian penambahan surfaktan dapat menghasilkan lebih dari satu fasa $\mathrm{TiO}_{2}$ [10], [11]. Rahayu et al [14] dalam penelitiannya membuat nanotitania dengan metode sol gel, yang divariasikan dengan penambahan etanolamina. Kemudian dikalsinasi pada suhu $500^{\circ} \mathrm{C}$ selama 4 jam, didapatkan bahwa penambahan etanolamina sebanyak $1 \mathrm{ml}$ fasa yang terbentuk adalah fasa anatase dan brukit dengan presentase berat 64,07\%wt dan 35,935\%wt, serta ukuran partikel dalam kisaran 19,8 $\mathrm{nm}$.

Sehingga dalam penelitian ini dilakukan kembali pembuatan $\mathrm{TiO}_{2}$ dengan metode sol gel. $\mathrm{TiO}_{2}$ dibuat dengan dengan memvariasikan surfaktan etanolamina 0 ; 0,$5 ; 1 ; 1,5 ;$ dan $2 \mathrm{ml}$. Etanolamina merupakan jenis surfaktan nonionik [15] Tujuan dari penelitian ini adalah untuk mengetahui pengaruh etanolamina terhadap pembentukan fasa, ukuran partikel, dan luas permukaan nanotitania.

\section{METODE PENELITIAN}

Penelitian ini menggunakan bahan titanium butoksida $\left(\mathrm{C}_{16} \mathrm{H}_{36} \mathrm{O}_{4} \mathrm{Ti}\right)$ (Sigma Aldrich), etanol $\left(\mathrm{C}_{2} \mathrm{H}_{5} \mathrm{OH}\right)$ (Merck), etanolamina (Merck), dan HCL 37\%. Metode penelitian ini terdiri atas beberapa tahap antara lain: sintesis, kalsinasi, dan uji karakterisasi sampel menggunakan XRD, 
TEM, dan SAA. Proses sintesis dilakukan dengan mencampurkan etanol $60 \mathrm{ml}$ dan Ti-Butoksida 5,25 ml dengan mikro pipet, larutan terus diputar selama \pm 20 menit dengan magnetic stirer, tahap selanjutnya yaitu dicampurkan etanolamina setetes demi tetes dengan variasi $(0,0.5,1,1.5$, dan $2 \mathrm{ml}$ ) menggunakan mikro pipet dengan tetap diaduk selama \pm 30 menit. Kemudian $\mathrm{HCl}$ dimasukkan setetes demi dengan tetap diaduk selama 24 jam. Setelah semua bahan tercampur, sampel akan dikeringkan menggunakan oven dengan suhu $200^{\circ} \mathrm{C}$ selama 24 jam, suhu dinaikkan secara bertahap.

Kalsinasi dilakukan untuk menghilangkan zat-zat yang tidak dibutuhkan dalam bubuk $\mathrm{TiO}_{2}$ dan kadar uap air yang berlebihan. Kalsinasi dilakukan selama 4 jam pada suhu $500^{\circ} \mathrm{C}$. Setelah proses kalsinasi, sampel yang berbentuk serbuk kemudian digerus secara manual menggunakan mortar dan pastel agate. Pada penelitian ini metode sintesis yang digunakan sama dengan penelitian Rahayu et al [14] tetapi pada penelitiannya hanya melakukan karakterisasi XRD pada dua sampel, serta tidak melakukan uji SAA untuk mengetahui nilai luas permukaannya. Sedangkan pada peneltian ini sampel serbuk $\mathrm{TiO}_{2}$ yang dihasilkan akan dikarakterisasi dengan XRD, TEM, dan SAA.

Data yang terekam pada karakterisasi

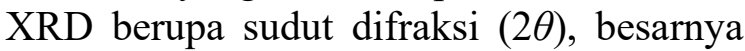
intensitas $(I)$ dan waktu pencatatan perlangkahan $(t)$. Sudut difraksi $(2 \theta)$ yang digunakan mulai dari $10^{\circ}$ sampai dengan $90^{\circ}$ dengan ukuran langkah $0,02^{\circ}$ dan scan time selama $10 \%$ menit. Alat yang digunakan dioperasikan dengan tegangan $40 \mathrm{kV}$ dan kuat arus $30 \mathrm{~mA}$. Data yang sudah diperoleh kemudian dianalisis menggunakan perangkat lunak High Score Plus (HSP). Analisis menggunakan HSP bertujuan untuk menganalisis data secara kualitatif. Kemudian analisis kuantitatif menggunakan perangkat lunak Rietica.
Hasil karakterisasi TEM diolah menggunakan perangkat lunak ImageJ untuk menghitung ukuran butiran partikel.

Karakterisasi SAA didasarkan pada siklus adsorpsi dan desorpsi isotermis gas nitrogen oleh sampel berupa serbuk pada suhu nitrogen cair, dengan cara sejumlah gas nitrogen yang diketahui dimasukkan ke dalam tabung sampel, maka sensor tekanan akan menghasilkan data tekanan proses yang bervariasi. Selanjutnya, data yang dihasilkan dari alat tersebut dihitung dengan metode BET untuk mencari luas permukaan.

\section{HASIL DAN PEMBAHASAN}

Hasil XRD dilakukan untuk analisis kualitatif guna mengetahui fasa kristal, dan analisis kuantitatif untuk mengetahui komposisi pada masing-masing fasa kristal, struktur kristal dan parameter sel.

Gambar 1 menunjukkan difaktogram XRD sampel $\mathrm{TiO}_{2}$ yang telah dikalsinasi pada suhu $500^{\circ} \mathrm{C}$. Tampak bahwa terdapat puncak difraksi tertinggi $2 \theta=25,32^{\circ}$ sampai $25,34^{\circ}$ mengindikasi fasa dari anatase (ICOD 01-078-2486) sesuai pada beberapa penelitian [10], [16], [17]. Selain itu, puncak yang mengindikasikan adanya fasa brukit (COD 96-900-4140) pada $2 \theta=$ $30,80^{\circ}$ serta fasa rutil (ICOD 01-076-1938) pada $2 \theta=27,41^{\circ}[10],[11],[16]$. Jika melihat Gambar 1, pada sampel A-0 dan A-0,5 puncak yang dominan muncul adalah anatase. Untuk sampel A-0,5 bisa disebabkan penambahan etanolamina yang terlalu sedikit, sehingga tidak menumbuhkan fasa lain. Hal yang sangat menarik dari penelitian ini adalah kemunculan fasa brukit dan rutil yang cukup memadai pada sampel A-1,0. 


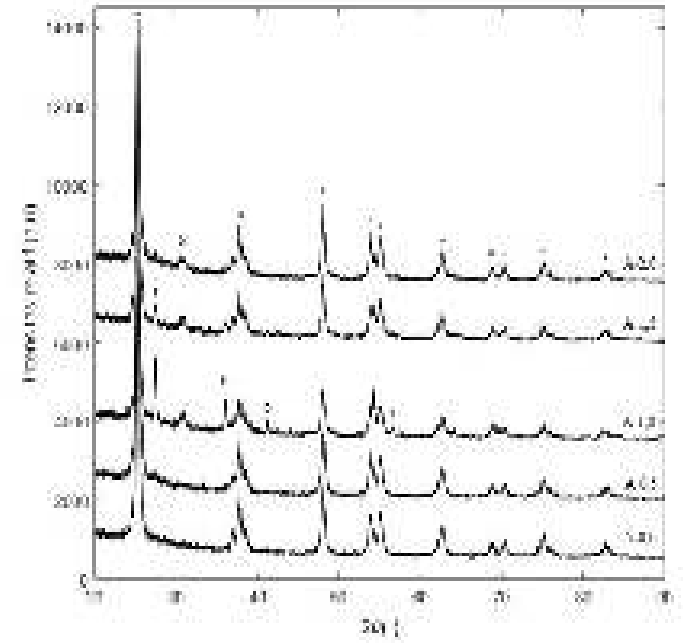

Gambar 1. Difaktogram XRD $\mathrm{TiO}_{2}$

A-0, A-0,5, A-1,0, A-1,5 dan A-2,0.

$*=$ anatase $\mathrm{b}=$ brukit dan $\mathrm{r}=$ rutil.

Kemunculan fasa brukit dan rutil sampel A-1,0 dapat dilihat pada Gambar 1. Pada beberapa penelitian fasa rutil baru muncul pada suhu di atas $500^{\circ} \mathrm{C}$ dan brukit muncul di bawah $500^{\circ} \mathrm{C}$ [18]-[20]. Namun dalam penelitian ini terutama pada sampel A-1,0 telah muncul fasa rutil dan masih menyisakan fasa brukit. Hal ini dapat difahami bahwa kehadiran etanolamina pada $1 \mathrm{ml}$ dapat menghasilkan fasa selain anatase. Penambahan surfaktan jenis nonionik pada sintesis $\mathrm{TiO}_{2}$ dapat menghasilkan fasa selain anatase [10], [16]. Fasa rutil dapat muncul jika saat proses sintesis sampel memiliki derajat hidrolisis yang rendah sehingga menyebabkan proses nukleasi yang menghasilkan cacat kisi dan mikrostrain, di mana fasa rutil dan brukit dapat terbentuk dalam fasa anatase [16], [21]-[23].

Selain faktor sintesis, hal lain penyebab munculnya fasa brukit dan rutil di bawah $500^{\circ} \mathrm{C}$ bisa disebabkan faktor $\mathrm{pH}$ pada sampel [11]. Menurut $\mathrm{Hu}$ et al (2003). sintesis $\mathrm{TiO}_{2}$ dengan $\mathrm{pH}$ rendah dapat memunculkan fasa brukit, pada penelitiannya fasa brukit dan rutil muncul pada sampel dengan $\mathrm{pH} 2$ dan suhu kalsinasi $500^{\circ} \mathrm{C}$, menurutnya semakin besar $\mathrm{pH}$ dan suhu kalsinasi maka fasa brukit tidak muncul. Seiring dengan penambahan etanolamina dilihat pada Gambar 1, bahwa fasa rutil mengalami penurunan intensitas. Ada banyak faktor yang terkait dalam hal tinggi rendahnya puncak intensitas difraksi suatu bahan. Salah satunya adalah tingkat kekristalan bahan dan posisi atom dalam sel satuan. Bergesernya posisi atom dapat meningkatkan dan mengurangi intensitas puncak XRD [24]. Analisis kuntitatif dilakukan untuk mengetahui komposisi setiap fasa-fasa tersebut, yang dilakukan dengan refinement data XRD menggunakan metode Rietveld. Model penghalusan yang digunakan untuk fasa anatase adalah Djerdj and Tonejc (2006) [25], model fasa rutil menggunakan Howard et al (1991) [26], dan model fasa brukit menggunakan Meagher and Lager (1979) [27]. Hasil penghalusan ditunjukkan dalam Gambar 2.

Dari Gambar 2 terlihat bahwa berdasarkan pola garis selisih antara data pengamatan (berwarna hitam) dan data input (berwarna merah) memiliki pola hasil perhitungan (berwarna hijau) hampir rata, yang berarti bahwa selisih antara hasil perhitungan dan data pengamatan relatif kecil. Selain itu dalam melakukan penghalusan difaktogram menggunakan metode Rietveld perlu diperhatikan nilai GOF (Godness of Fit). Nilai GOF yang disimbolkan dengan $2 \leq 4$ sudah dapat diterima. Selain itu untuk nilai $R_{w p}, R_{p}$, dan $R_{\text {exp }}$ harus kurang dari 20.

Setelah selesai masing-masing data dapat dilihat harga $R$ pada file output Seperti yang disajikan pada Tabel 1. Berdasarkan data pada Tabel 1 penghalusan pada seluruh sampel menunjukkan nilai $R_{w p}, R_{p}$, dan $R_{\exp }$ kurang dari 20 dan nilai GOF kurang dari 4. Selain faktor $R$, hasil analisis kuantitatif dapat memberikan nilai persen berat (\%wt) masing-masing fasa dalam sampel seperti yang disajikan pada Tabel 2 .

Dari Table 2 dapat dilihat bahwa penambahan etanolamina $0,5 \mathrm{ml}$ tidak memberikan pengaruh kehadiran fasa lain selain anatase. Penambahan etanolamina 1; 
1,5; dan $2 \mathrm{ml}$ dapat menghasilkan fasa brukit dan rutil dengan presentase berat maksimum pada $1 \mathrm{ml}$. Selain itu dari Tabel 2 juga menunjukkan bahwa berat kandungan fasa anatase semakin naik dengan seiring penambahan etanolamina tetapi menurunkan kandungan fasa rutil dan brukit. Dengan kata lain, penambahan surfaktan akan meningkatkan stabilitas dari fasa anatase sehingga akan menghasilkan

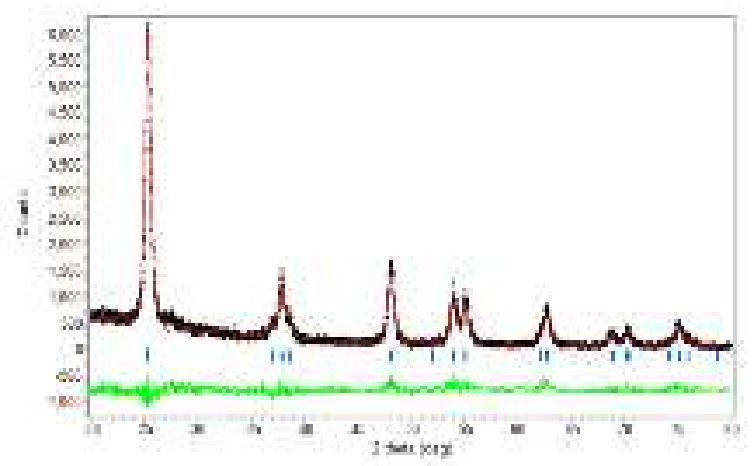

(a)

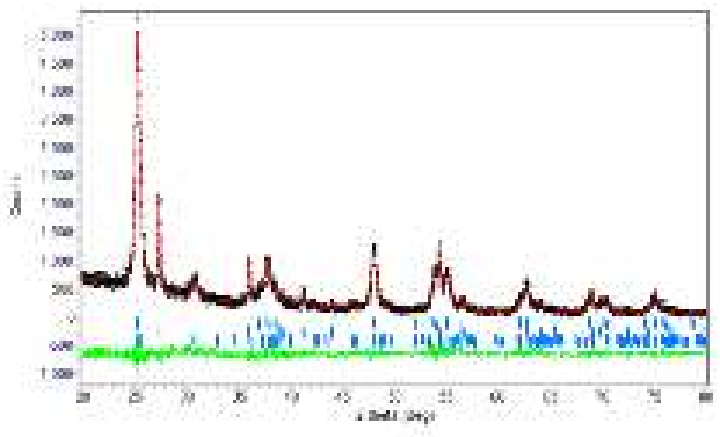

(c) fasa brukit dan rutil yang semakin mengecil, karena stabilitas dari fasa anatase semakin meningkat dengan meningkatnya surfaktan yang diberikan [21]. Selain digunakan untuk mengetahui presentase fasa, analisis secara kuantitatif dapat juga digunakan untuk menentukan struktur dan grup ruang kristal pada suatu bahan.

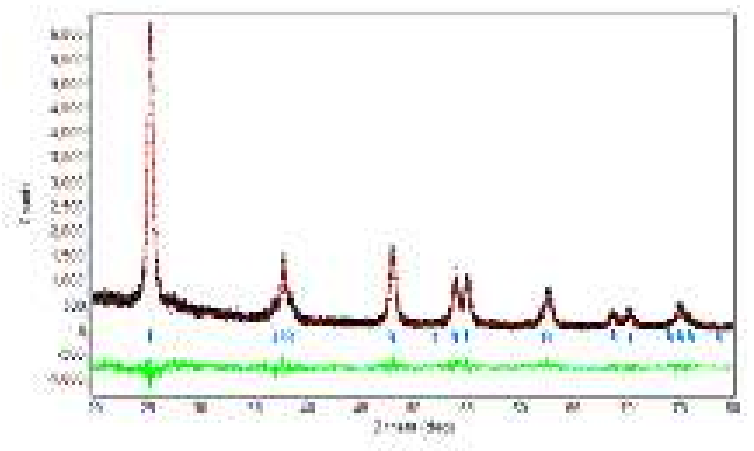

(b)

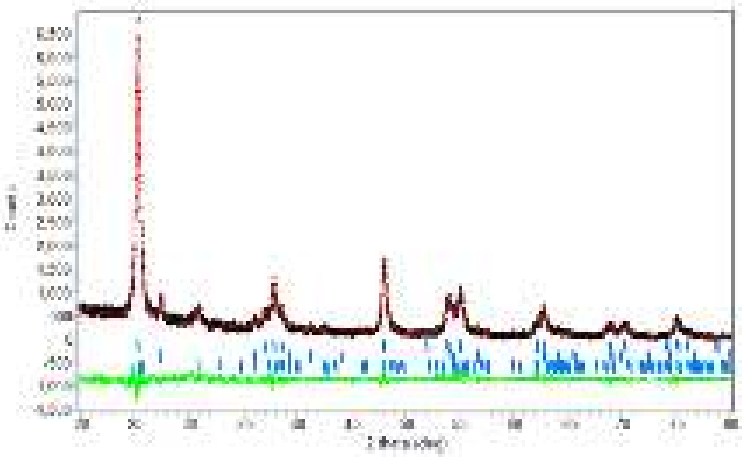

(d)

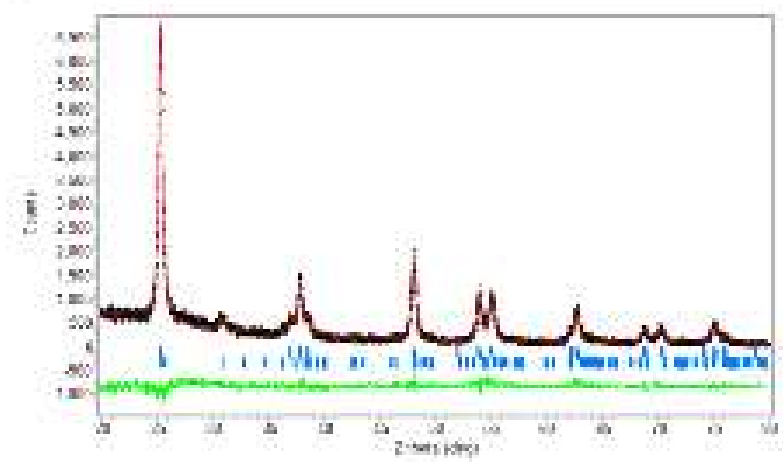

(e)

Gambar 2. Hasil refinement data $\mathrm{XRD} \mathrm{TiO}_{2}$ (a) A- 0,0,0 (b) A-0,0,5 (c) A-1,0 (d) A-1,5 (e) A-2,0 
Tabel 1. Perhitungan ukuran partikel dari hasil XRD.

\begin{tabular}{lccccccc}
\hline Sampel & $K$ & $2 \theta\left({ }^{\circ}\right)$ & $\theta\left({ }^{\circ}\right)$ & $\lambda(\AA)$ & $F W H M\left({ }^{\circ}\right)$ & $L(\mathrm{~nm})$ & $\begin{array}{c}\text { Perhitungan } \\
\text { TEM (nm) }\end{array}$ \\
\hline A-0 & 0,9 & 25,32 & 12,65 & 1,54059 & 0,483 & 16,8 & \\
A-0,5 & 0,9 & 25,30 & 12,652 & 1,54059 & 0,550 & 14,8 & \\
A-1,0 & 0,9 & 25,30 & 12,6455 & 1,54059 & 0,553 & 14,7 & $16 \pm 1$ \\
A-1,5 & 0,9 & 25,32 & 12,65 & 1,54059 & 0,453 & 17,9 & \\
A-2,0 & 0,9 & 25,34 & 12,6525 & 1,54059 & 0,431 & 18,8 & \\
\hline
\end{tabular}

Dengan nilai GOF kurang dari 4 yang dilihat dari hasil Tabel 2, maka dapat dikatakan pada sampel ini kristal $\mathrm{TiO}_{2}$ yang dihasilkan memiliki kemiripan struktur cukup tinggi dengan model. Berdasarkan model tersebut, maka kristal anatase memiliki struktur tetragonal dengan grup ruang 141/AMD, brukit memiliki struktur ortorombik dengan grup ruang PBCA, dan rutil memiliki struktur tetragonal dengan grup ruang $\mathrm{P} 42 / \mathrm{M} \mathrm{N} \mathrm{M}$.

Selain struktur kristal, dapat diketahui juga nilai sel parameter untuk setiap fasa yang diperoleh dari keluaran penghalusan sampel seperti yang disajikan pada Tabel 4. Dari Tabel 4 dapat diamati nilai parameter sel yang paling kecil baik untuk fasa anatase, rutil dan brukit dimiliki sampel A-1,0. Selain itu sel parameter $a$ fasa anatase memiliki kecenderungan turun kemudian naik seiring dengan naiknya konsentrasi etanolamina, hal yang sama juga terlihat pada sel parameter $c$ fasa anatase, sementara pada fasa brukit dan rutil nilai sel parameter cenderung naik seiring dengan naiknya konsentrasi etanolamina. Hal yang sama terdapat pada penelitian yang dilakukan oleh Fahyuan et al (2013) [21], menurutnya terdapat konsentrasi optimum surfaktan yang dapat mempengaruhi perubahan sel parameter.

Hasil TEM dilakukan pada sampel A1,0 dengan skala bar $50 \mathrm{~nm}$ dan $20 \mathrm{~nm}$. Adapun hasil analisis morfologi dan distribusi ukuran partikel ditunjukkan pada Gambar 5. Dalam pengukuran ini, untuk skala bar $50 \mathrm{~nm}$ diambil 20 partikel dengan ukuran yang berbeda, dan skala bar $20 \mathrm{~nm}$ diambil 15 partikel dengan ukuran berbeda untuk memperoleh rata-rata ukuran partikel Dari kedua gambar TEM ini baik sekala bar 50 dan $20 \mathrm{~nm}$ memberikan hasil masingmasing $15 \pm 0,2 \mathrm{~nm}$ dan $17 \pm 0,4 \mathrm{~nm}$. Sehingga secara rata-rata hasilnya adalah $16 \pm 1 \mathrm{~nm}$. Dengan demikian dari segi ukuran partikel berdasarkan hasil TEM ini, klasifikasi sampel dapat masuk ke kelompok nanopartikel [28]. Dari kedua gambar TEM ini sampel dapat dikatakan tidak mengalami perlengketan antara partikel-partikel sehingga partikel-partikel tidak mengalami adhesion [29], dan bentuk partikel secara umum masuk bentuk bola (spheris) seperti pada penelitian yang dilakukan oleh Vijayalakshmi and Rajendra (2010) [30].

Tabel 2. Parameter kesesuain refinement data XRD $\mathrm{TiO}_{2}$

\begin{tabular}{lcccc}
\hline Sampel & $R_{w p}$ & $R_{p}$ & $R_{\exp }$ & GoF \\
\hline A-0 & 15,26 & 11,01 & 10,20 & 2,2 \\
A-0,5 & 15,15 & 11,01 & 10,20 & 2,2 \\
A-1,0 & 14,63 & 10,56 & 10,21 & 2,0 \\
A-1,5 & 14,40 & 10,33 & 10,22 & 2,0 \\
A-2,0 & 14,80 & 10,67 & 10,41 & 2,0 \\
\hline
\end{tabular}

Tabel 3. Presentase fasa $\mathrm{TiO}_{2}$ dalam persen berat $(\% \mathrm{wt})$

\begin{tabular}{lccc}
\hline Sampel & $\begin{array}{c}\text { Anatase } \\
(\% w t)\end{array}$ & $\begin{array}{c}\text { Brukit } \\
(\% \mathrm{wt})\end{array}$ & $\begin{array}{c}\text { Rutil } \\
(\% \mathrm{wt})\end{array}$ \\
\hline A-1,0 & $58 \pm 2$ & $27 \pm 2$ & $15 \pm 0,4$ \\
A-1,5 & $70 \pm 2$ & $25 \pm 2$ & $5 \pm 0,3$ \\
A-2,0 & $79 \pm 2$ & $21 \pm 2$ & \\
\hline
\end{tabular}


yang telah melakukan sintesis $\mathrm{TiO}_{2}$ dengan berbagai jenis surfaktan menggunakan metode sol gel, hasilnya partikel memiliki bentuk bola karena misel pada surfaktan membentuk bola selama reaksi dalam sampel $\mathrm{TiO}_{2}$.

Hasil analisis XRD juga dapat digunakan untuk mengetahui ukuran partikel dari $\mathrm{TiO}_{2}$ yang ditunjukkan pada Tabel 5 yaitu dengan cara menganalisis puncak tertinggi. Perubahan intensitas dan lebar puncak difraksi XRD dengan penambahan surfaktan menunjukkan bahwa surfaktan berpengaruh pada ukuran partikel [31]. Dari Tabel 5 dapat dilihat bahwa semakin kecil nilai FWHM (Full Widht at Half Maximum) yang diperoleh, maka ukuran kristal akan semakin besar. Nilai FWHM terbesar yaitu pada sampel A-1,0 dengan penambahan etanolamina sebanyak $1 \mathrm{ml}$, dengan demikian ukuran partikel pada sampel A-1,0 terkecil yaitu 14,7 nm. Hasil ini tidak terlalu berbeda dengan pengukuran ukuran partikel menggunakan TEM yang menghasilkan $16 \pm 1 \mathrm{~nm}$. Dapat dilihat pula nilai ukuran partikel mempunyai kesamaan dengan sel parameter yang ditunjukkan pada Tabel 4, dimana semakin bertambahnya etanolamina didapatkan nilai ukuran partikel mengalami kenaikan dengan nilai sel parameter semakin besar,
Sehingga dapat dikatakan terdapat konsentrasi optimum yang mempengaruhi ukuran parikel dan sel parameter yang terdapat pada sampel A-1,0. Hal tersebut bisa dikarenakan penambahan etanolamina $1 \mathrm{ml}$ dekat dengan batas konsentrasi kritis dari etanolamina.

Penambahan etanolamina $0,5 \mathrm{ml}$ menghasilkan ukuran kristal terkecil kedua, hal tersebut dapat dikarenakan penambahan surfaktan di bawah konsentrasi kritis, sehingga misel dari surfaktan tersebut belum terbentuk, dan peran surfaktan sebagai pereduksi ukuran kristal belum secara optimum. Suatu surfaktan akan membentuk misel jika batas konsentrasi dari surfaktan tersebut telah tercapai, sedangkan pada sampe A-1,5 dan A-2,0 menghasilkan ukuran kristal yang bertambah besar. Hal ini mengindikasi terdapatnya batas optimum penambahan etanolamina agar diperoleh ukuran kristal yang semakin mengecil [32]

Hasil SAA digunakan untuk mengetahui luas permukaan spesifik dari sampel, maka dilakukan uji menggunakan SAA dengan metode BET. Luas permukaan spesifik metode BET dihitung melalui proses adsorpsi-desorpsi nitrogen pada kondisi setimbang dalam suhu nitrogen cair (77 K) menggunakan SAA Quantachrome NOVA 1000 e versi 11.0.

Tabel 4. Parameter sel $\mathrm{TiO}_{2}$

\begin{tabular}{lcccccc}
\hline \multirow{2}{*}{ Fasa } & $\begin{array}{c}\text { Parameter } \\
\text { sel }(\AA)\end{array}$ & \multicolumn{5}{c}{ Sampel } \\
\cline { 3 - 7 } Anatase & $a=b$ & 3,7841 & 3,7840 & 3,7838 & 3,7849 & 3,7852 \\
& $c$ & 9,5075 & 9,5070 & 9,5035 & 9,5074 & 9,5076 \\
\multirow{2}{*}{ Brukit } & $a$ & - & - & 9,1616 & 9,1792 & 9,1796 \\
& $b$ & - & - & 5,4390 & 5,4403 & 5,4436 \\
& $c$ & - & - & 5,1532 & 5,1552 & 5,1621 \\
\multirow{2}{*}{ Rutil } & $a=b$ & - & - & 4,5950 & 4,5982 & - \\
& $c$ & - & - & 2,9522 & 2,9572 & - \\
\hline
\end{tabular}




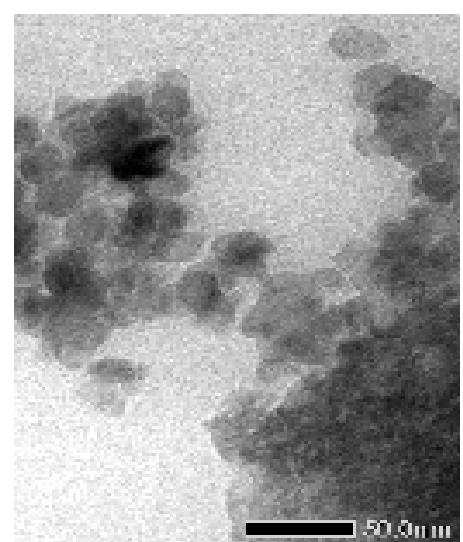

(a)

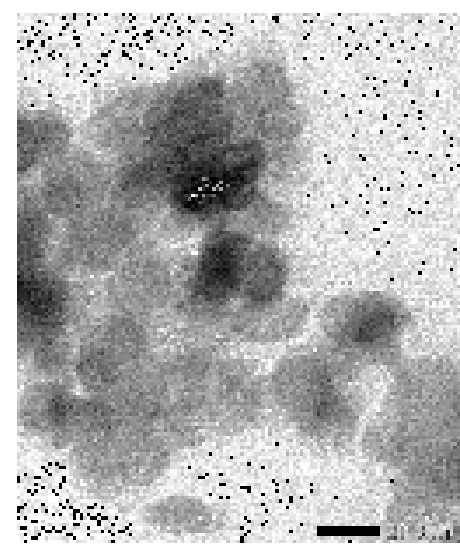

(b)

Gambar 5. Hasil TEM sampel A-1,0 $\mathrm{TiO}_{2}$ (a) dengan skala bar $50 \mathrm{~nm}$ dan (b) dengan skala bar 20nm.

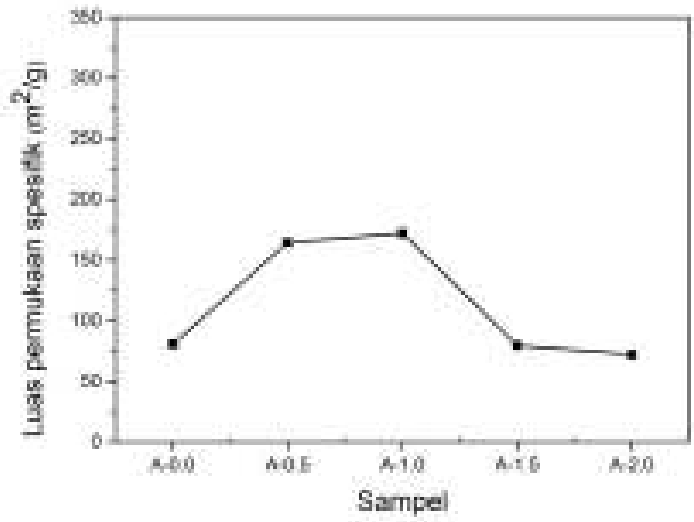

Gambar 6. Grafik luas permukaan spesifik

Gambar 6 merupakan hasil dari luas permukaan spesifik sampel $\mathrm{TiO}_{2}$. Untuk luas permukaan spesifik terkecil ada pada sampel A-2,0 sebesar 72,072 $\mathrm{m}^{2} / \mathrm{g}$ sedangkan untuk luas permukaan spesifik terbesar diperoleh pada sampel A-1,0 dengan nilai $172,239 \mathrm{~m}^{2} / \mathrm{g}$. Sampel A-0,0 memiliki luas permukaan spesifik 80,680 $\left(\mathrm{m}^{2} / \mathrm{g}\right)$. Sampel A-0,5 luas permukaan spesifik 164,376 (m²/g). Kemudian sampel A-1,5 didapatkan dan luas permukaan spesifik 79,72 $\left(\mathrm{m}^{2} / \mathrm{g}\right)$. Analisis luas permukaan dapat menunjukkan peningkatan dan penurunan luas permukaan $\mathrm{TiO}_{2}$ dengan penambahan etanolamina yang berbeda-beda. Hal yang menarik dari nilai luas permukaan spesifik adalah adanya keterkaitan dengan sel parameter dari hasil penghalusan Tabel 4 dan ukuran partikel Tabel 5, yaitu saat nilai sel parameter menurun, ukuran partikel juga menurun tetapi nilai luas permukaan spesifik pada sampel meningkat. Hal tersebut sesuai dengan teori Cullity (1978) [24].

Penggunaan surfaktan nonionik pada sintesis $\mathrm{TiO}_{2}$ diketahui dapat menghasilkan luas permukaan yang cukup besar jika dibandingkan surfaktan lainnya [16], [31].

Selain itu dapat katakan semakin besar nilai luas permukaan spesifik sampel, maka pori dan volume pori dari sampel bertambah [33].

\section{KESIMPULAN}

Berdasarkan hasil karakterisasi XRD, TEM dan SAA didapatkan bahwa sampel A-1,0 merupakan sampel dengan hasil paling baik, dilihat dari ukuran partikel paling kecil yaitu $16 \pm 1 \mathrm{~nm}$ berdasarakan karakterisasi TEM, dan 14,7 nm berdasarkan perhitungan dari karakterisasi XRD serta dengan ukuran partikel paling kecil maka sampel A-1,0 memiliki luas 
permukaan spesifik paling besar, sehingga diharapkan mampu memiliki hasil yang baik dalam pemanfaatan uji fotokatalis.

\section{UCAPAN TERIMAKASIH}

Penulis mengucapkan terimakasih kepada Dikti yang telah mendanai penelitian ini melalui skema penelitian hibah Pascasarjana dengan nomor kontrak: 3869/UN26.21/PN/2020.

\section{DAFTAR PUSTAKA}

[1] B. Y. Xia et al., "One-Dimensional Nanostructures : Synthesis,

Characterization , and Applications" no. 5, pp. 353-389, 2003.

[2] Ducan and L. F. Sutherland, Nanotechnologies: Principles, Applications, Implications and Hands-on Activities. In Handbook of Research and Inovation Industrial and Tecnologies. European Comission. 2012.

[3] E. M. Mahdi, M. Hamdi, M. S. M. Yusoff, and P. Wilfred, "XRD and EDXRF Analysis of Anatase Nano$\mathrm{TiO}_{2}$ Synthesized from Mineral Precursors," Adv. Mater. Res., vol 620, pp. 179-185, 2013

[4] W. Maziarz, " $\mathrm{TiO}_{2} / \mathrm{SnO}_{2}$ and $\mathrm{TiO}_{2}$ $/ \mathrm{CuO}$ Thin Film NanoHeterostructures as Gas Sensors," Appl. Surf. Sci., vol. 480, no. February, pp. 361-370, 2019.

[5] M. Mohammadi, M. Rezaee Roknabadi, M. Behdani, and A. Kompany, "Enhancement of Visible and UV Light Photocatalytic Activity of $\mathrm{rGO}^{-\mathrm{TiO}_{2}}$ Nanocomposites: The effect of $\mathrm{TiO}_{2}$ /Graphene Oxide Weight Ratio," Ceram. Int., vol. 45, no. 10, pp. 12625-12634, 2019.

[6] J. Singh, S. A. Khan, J. Shah, R. K. Kotnala, and S. Mohapatra, "Nanostructured $\mathrm{TiO}_{2}$ Thin Films
Prepared by RF Magnetron Sputtering for Photocatalytic Applications," Appl. Surf. Sci., vol. 422, pp. 953-961, 2017.

[7] Y. W. Myint, T. T. Moe, W. Y. Linn, A. Chang, and P. P. Win, "The Effect of Heat Treatment on Phase Transformation and Morphology of Nano-Crystalline Titanium Dioxide $\mathrm{TiO}_{2}$," Int. J. Sci. Technol. Res., vol. 6, no. 6, pp. 293-299, 2017.

[8] J. Park, J. Joo, G. K. Soon, Y. Jang, and T. Hyeon, "Synthesis of Monodisperse Spherical Nanocrystals," Angew. Chemie - Int. $E d$., vol. 46, no. 25 , pp. 4630-4660, 2007.

[9] M. Malekshahi Byranvand, A. Nemati Kharat, L. Fatholahi, and Z. Malekshahi Beiranvand, "A Review on Synthesis of Nano- $\mathrm{TiO}_{2}$ via Different Methods," J. Nanostructures, vol. 3, no. 1, pp. 19, 2013.

[10] O. L. Galkina, V. V. Vinogradov, A. V. Agafonov, and A. V. Vinogradov, "Surfactant-Assisted Sol-Gel Synthesis of $\mathrm{TiO}_{2}$ with Uniform Particle Size Distribution", Int. J. Inorg. Chem., vol. 2011, pp. 1-8, 2011.

[11] Y. Hu, H. L. Tsai, and C. L. Huang, "Effect of Brookite Phase on the Anatase-Rutile Transition in Titania Nanoparticles," J. Eur. Ceram. Soc., vol. 23, no. 5, pp. 691-696, 2003.

[12] C. S. Kim, B. K. Moon, J. H. Park, S. T. Chung, and S. M. Son, "Synthesis of Nanocrystalline $\mathrm{TiO}_{2}$ in Toluene by a Solvothermal Route," J. Cryst. Growth, vol. 254, no. 3-4, pp. 405410, 2003.

[13] N. B. Chaure, A. K. Ray, and R. Capan, "Sol-Gel Derived Nanocrystalline Titania Thin Films on Silicon," Semicond. Sci. Technol., vol. 20, no. 8, pp. 788-792, 2005.

[14] R. Rahayu, P. Manurung, and Y. 
Yulianti, "Pengaruh Ethanolamina (MEA) dalam Pembentukan $\mathrm{TiO}_{2}$ dari Bahan Awal Ti Butoksida," J. Teor. dan Apl. Fis., vol. 07, no. 02, pp. 153-160, 2019.

[15] B. Burczyk, K. A. Wilk, A. Sokołowski, and L. Syper, "Synthesis and Surface Properties of $\mathrm{N}$-alkyl-N-methylgluconamides and N-alkyl-N-methyllactobionamides," J. Colloid Interface Sci., vol. 240, no. 2, pp. 552-558, 2001.

[16] S. M. Abdel-Azim, A. K. AboulGheit, S. M. Ahmed, D. S. ElDesouki, and M. S. A. AbdelMottaleb, "Preparation and Application of Mesoporous Nanotitania Photocatalysts Using Different Templates and $\mathrm{pH}$ Media," Int. J. Photoenergy, vol. 2014, 2014.

[17] Manurung, P., Situmeang, R., Sinuhaji, P, Sembiring, S. "Effect of Sulfur Doped Nanotitania for Degradation of Remazol Yellow and Phenol," vol. 32, no. 12, pp. 30193023, 2020.

[18] D. Dastan, N. Chaure, and M. Kartha, "Surfactants Assisted solvothermal Derived Titania Nanoparticles: Synthesis and Simulation," J. Mater. Sci. Mater. Electron., vol. 28, no. 11, pp. 7784 7796, 2017.

[19] B. K. Mutuma, G. N. Shao, W. D. Kim, and H. T. Kim, "Sol-gel Synthesis of Mesoporous AnataseBrookite and Anatase-BrookiteRutile $\mathrm{TiO}_{2}$ Nanoparticles and Their Photocatalytic Properties," J. Colloid Interface Sci., vol. 442, pp. 1-7, 2015.

[20] S. Bakardjieva et al., "Transformation of Brookite-Type TiO 2 nanocrystals to rutile: Correlation Between Microstructure and Photoactivity," J. Mater. Chem., vol. 16, no. 18, pp. 1709-1716, 2006.

[21] H. D. Fahyuan, D. Dahlan, and A. -,
"Pengaruh Konsentrasi CTAB dalam Sintesis Nanopartikel $\mathrm{TiO}_{2}$ untuk Aplikasi Sel Surya Menggunakan Metode Sol Gel," J. Ilmu Fis. Univ. Andalas, vol. 5, no. 1, pp. 16-23, 2013.

[22] S. Sahni, S. B. Reddy, and B. S. Murty, "Influence of Process Parameters on the Synthesis of Nano-Titania by Sol-Gel Route," Mater. Sci. Eng. A, vol. 452-453, pp. 758-762, 2007.

[23] P. P. Bidaye and J. B. Fernandes, "A Rapid and Facile Synthesis Method for Nanosize Rutile Phase TiO with High Photocatalytic Activity," Green Sustain. Chem., vol. 09, no. 02, pp. 27-37, 2019.

[24] B. Cullity, Element of X-Ray Diffraction. Addion- Wsley Publishing Company Inc: Massachusetts, 1978.

[25] I. Djerdj and A. M. Tonejc, "Structural Investigations of Nanocrystalline $\mathrm{TiO}_{2}$ Samples," $J$. Alloys Compd., vol. 413, no. 1-2, pp. 159-174, 2006.

[26] C. J. Howard, T. M. Sabine, and F. Dickson, "Structural and Thermal Parameters for Rutile and Anatase," Acta Crystallogr. Sect. B, vol. 47, no. 4, pp. 462-468, 1991.

[27] E. P. Meagher and G. A. Lager, "Thermal in the $\mathrm{TiO}_{2}$, Polymofphs: And Refinement Of The Crystal Structures Of Rutile Brookite at High Temperature" Can. Mineral., vol. 17, pp. 77-85, 1979.

[28] R. N. Primy and I. K. Muwarni, "Sintesis dan Karakterisasi Padatan $\mathrm{Fe}_{2} \mathrm{O}_{3} / \mathrm{CaF}_{2}$," J. Sains Dan Seni Its, vol. 1, no. 1, pp. 6-8, 2012.

[29] E. Huseynov, A. Garibov, and R. Mehdiyeva, "TEM and SEM Study of $\mathrm{Nano} \mathrm{SiO}_{2}$ Particles Exposed to Influence of Neutron Flux," $J$. Mater. Res. Technol., vol. 5, no. 3, pp. 213-218, 2016. 
[30] R. Vijayalakshmi and V. Rajendran, "Impact of Surfactants on Physical

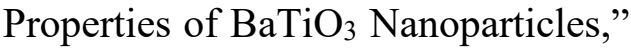
Int. J. Nanosci., vol. 12, no. 1, pp. 15, 2013.

[31] I. Jang, H. J. Leong, and S. G. Oh, "Effects of Surfactants on the Preparation of $\mathrm{TiO}_{2}$ Nanoparticles in Microwave-Assisted Sol-Gel Process and Their Photocatalytic Activity," Korean J. Chem. Eng., vol. 33, no. 5, pp. 1647-1652, 2016.

[32] C. de O. Rangel Yagui, A. Pessoa, and L. C. Tavares, "Micellar Solubilization of Drugs," J. Pharm.
Pharm. Sci., vol. 8, no. 2, pp. 147163, 2005.

[33] S. Estrada Flores, A. MartínezLuévanos, C. M. Perez-Berumen, L. A. García-Cerda, and T. E. FloresGuia, "Relationship Between Morphology, Porosity, and the Photocatalytic Activity of $\mathrm{TiO}_{2}$ Obtained by Sol-Gel Method Assisted with Ionic and Nonionic Surfactants," Bol. la Soc. Esp. Ceram. y Vidr., vol. 59, no. 5, pp. 209-218, 2020. 
Renita Maharani Fauzi, dkk.: Pengaruh Etanolamina terhadap Pembentukan Fasa, Ukuran Partikel, dan Luas Permukaan Spesifik Nanotitania Menggunakan Metode Sol Gel 